\title{
Supporting Information Materials for tert-Butyl 2-Pyridyl Nitroxide Available as a Paramagnetic Chelate Ligand for Strongly Exchange-Coupled Metal-Radical Compounds
}

\author{
Atsushi Okazawa, Takashi Nogami, and Takayuki Ishida* \\ Department of Applied Physics and Chemistry and Course of Coherent Optical Science, The University of \\ Electro-Communications, Chofu, Tokyo 182-8585, Japan
}

\section{Experimental Details.}

\section{Preparation of $N$-t-butyl- $N$-2-pyridylhydroxylamine (2pyNOH)}

A hexane solution of butyllithium $\left(1.6 \mathrm{~mol} \mathrm{~L}^{-1} ; 28.5 \mathrm{~mL} ; 46 \mathrm{mmol}\right)$ was added to an ether solution $(80 \mathrm{~mL})$ of 2-bromopyridine $(4.3 \mathrm{~mL} ; 45 \mathrm{mmol})$ at $-78^{\circ} \mathrm{C}$, and the mixture was stirred for 30 min under dry $\mathrm{N}_{2}$. An ether solution $(80 \mathrm{~mL})$ containing 2-methyl-2-nitrosopropane $(4.0 \mathrm{~g}, 46 \mathrm{mmol})$ was added to the above solution over 1 h. The cooling bath was removed, and the reaction vessel was allowed to stand at room temperature. After quenching with aqueous saturated $\mathrm{NH}_{4} \mathrm{Cl}$, aqueous $\mathrm{NaHCO}_{3}$ was added and the mixture was extracted with $\mathrm{CH}_{2} \mathrm{Cl}_{2}$. The organic layer was dried over anhydrous $\mathrm{MgSO}_{4}$, filtered, and concentrated. The products were separated by silica-gel column chromatography eluted with $1 / 2 \mathrm{CH}_{2} \mathrm{Cl}_{2}$ /ether to give $2 \mathrm{pyNOH}$ as a colorless solid (3.04 g; $18.3 \mathrm{mmol})$ in $41 \%$ yield. $\mathrm{Mp} 40-42^{\circ} \mathrm{C} .{ }^{1} \mathrm{H} \mathrm{NMR}\left(\mathrm{CDCl}_{3}, 270 \mathrm{MHz}\right) \delta 1.24(\mathrm{~s}, 9 \mathrm{H}), 7.02(\mathrm{ddd}, J=7.3$, 4.9, $1.1 \mathrm{~Hz}, 1 \mathrm{H}), 7.11(\mathrm{dt}, J=8.1,1.1 \mathrm{~Hz}, 1 \mathrm{H}) 7.60(\mathrm{ddd}, J=8.1,7.3,1.6 \mathrm{~Hz}, 1 \mathrm{H}), 7.74(\mathrm{broad}, 1 \mathrm{H}), 8.33(\mathrm{ddd}, J$ $=4.9,1.6,1.1 \mathrm{~Hz}, 1 \mathrm{H}) \cdot{ }^{13} \mathrm{C} \mathrm{NMR}\left(\mathrm{CDCl}_{3}, 68 \mathrm{MHz}\right.$; in the presence of a trace amount of phenylhydrazine $\left.{ }^{1}\right) \delta$ 26.4, 61.8, 117.5, 119.3, 136.6, 146.2, 161.4. IR (KBr disc) 802, 1200, 1360, 1431, 1587, 2987, $3230 \mathrm{~cm}^{-1}$. MS (EI, $70 \mathrm{eV}) \mathrm{m} / \mathrm{z}$ 166.1($\left(\mathrm{M}^{+}\right), 135.0,110.0,109.0,92.0,79.0,57.0$.

\section{Preparation of $\left[\mathrm{Ni}(2 \mathrm{pyNO})_{2}\left(\mathrm{H}_{2} \mathrm{O}\right)_{2}\right] \cdot\left(\mathrm{ClO}_{4}\right)_{2}(1)$}

Freshly prepared $\mathrm{Ag}_{2} \mathrm{O}$ (278 $\left.\mathrm{mg}, 1.20 \mathrm{mmol}\right)$ was added to a dichloromethane solution $(5 \mathrm{~mL})$ containing 2pyNOH (67 mg, $0.40 \mathrm{mmol})$, and the suspension was stirred at room temperature for $1 \mathrm{~h}$. After the solids were centrifuged and filtered off, the filtrate was concentrated to give a volume of ca. $1 \mathrm{~mL}$ under reduced pressure at room temperature. Immediately $\mathrm{Ni}\left(\mathrm{ClO}_{4}\right)_{2} \cdot 6 \mathrm{H}_{2} \mathrm{O}(73 \mathrm{mg}, 0.20 \mathrm{mmol})$ in ethanol $(2 \mathrm{~mL})$ was added to the above solution and the resultant mixture was allowed to stand in a refrigerator for 1 day. After ether $(3 \mathrm{~mL})$ was added 
to the solution, dark red powder of $\mathbf{1}$ was precipitated and collected on a filter (106 $\mathrm{mg} ; 0.170 \mathrm{mmol}$; yield 85\%).

Dark red crystals of $\mathbf{1}$ were obtained by slow ether-vapor diffusion into an acetonitrile solution. IR ( $\mathrm{KBr}$ disc) 627, 771, 1090, 1144, 1437, 1589, 2991, $3429 \mathrm{~cm}^{-1}$. Anal. Calcd.: C, 34.46; H, 4.85; N, 8.98\%. Found: C, 34.89; $\mathrm{H}, 4.92 ; \mathrm{N}, 8.82 \%$.

\section{Preparation of $\left[\mathrm{Cu}(2 \mathrm{pyNO})_{2}\left(\mathrm{ClO}_{4}\right)_{2}\right](2)$}

According to a similar procedure for 1, crude 2pyNO (prepared from 2pyNOH (33 mg; $0.20 \mathrm{mmol})$ ) and $\mathrm{Cu}\left(\mathrm{ClO}_{4}\right)_{2} \bullet 6 \mathrm{H}_{2} \mathrm{O}(37 \mathrm{mg}, 0.10 \mathrm{mmol})$ were mixed in dichloromethane $(1 \mathrm{~mL})$ and ethanol $(3 \mathrm{~mL})$, and the mixture was allowed to stand in a refrigerator for 1 day. Black block crystals of $\mathbf{2}$ were precipitated and collected on a filter (18 mg; $0.031 \mathrm{mmol}$; yield 31\%). They were suitable for X-ray diffraction and magnetic studies. IR (KBr disc) 623, 787, 1055, 1103, 1439, 1591, $2993 \mathrm{~cm}^{-1}$. Anal. Calcd.: C, 36.47; H, 4.42; N, 9.45\%. Found: C, 36.78; $\mathrm{H}, 4.19 ; \mathrm{N}, 9.63 \%$.

\section{X-Ray crystal structure analysis}

Diffraction data of $\mathbf{1}$ and $\mathbf{2}$ were collected on a Rigaku R-axis RAPID diffractometer with graphite monochromated Mo $K \alpha(\lambda=0.71069 \AA)$ radiation. The structures were solved by direct methods and expanded using Fourier techniques in the CrystalStructure program package. ${ }^{2}$ Numerical absorption correction was used. Full-matrix least-squares methods were applied using all of the unique reflection data. All of the hydrogen atoms in $\mathbf{1}$ were found experimentally, and their parameters were included in the refinement. The thermal displacement parameters of non-hydrogen atoms were refined anisotropically and those of hydrogen atoms were refined isotropically. As for $\mathbf{2}$, all of the hydrogen atoms were located at calculated positions and the parameters were refined as "riding".

\section{Magnetic susceptibility measurements}

Magnetic susceptibilities of the polycrystalline samples of $\mathbf{1}$ and $\mathbf{2}$ were measured on a Quantum Design MPMS SQUID magnetometer at an applied magnetic field of 500 or 5000 Oe in a temperature range down to 1.8 K. The magnetic response was corrected with diamagnetic blank data of the sample holder obtained separately. The diamagnetic contribution of the sample itself was estimated from Pascal's constant.

\section{Molecular orbital calculation}

Molecular orbital calculations were performed on the Gaussian03 program. $^{3}$ We applied unrestricted density functional (DFT) UB3LYP methods with the Becke exchange functional ${ }^{4}$ and the Lee-Yang-Parr correlation functional. ${ }^{5}$ The $6-31 \mathrm{G}(\mathrm{d}, \mathrm{p})$ basis set was chosen. The convergence criterion for the energy was set at 
$10^{-9}$ a.u. The structural parameters were given from the crystallographic data. The spin density surfaces were drawn in Figure 3 at the isovalue of 0.0025 . The SCF energies of the singlet and quintet states of $\mathbf{1}^{2+}$ were converged to -2730.59618231 and -2730.59959420 a.u., respectively, and those of the doublet and quartet states of 2 were -4232.31131549 and -4232.30785564 a.u., respectively. To check a basis-set dependence, we also selected the Lanl2dz basis set. The SCF energies of the singlet and quintet states of $\mathbf{1}^{2+}$ were converged to -1391.50325085 and -1391.50657389 a.u., respectively, and those of the doublet and quartet states of 2 were -1896.64866293 and -1896.64528295 a.u., respectively. Both calculations (UB3LYP/6-31(d,p) and UB3LYP/Lanl2dz) indicated the quintet (high-spin) ground state for $\mathbf{1}^{2+}$ and the doublet (low-spin) ground state for 2 .

\section{References}

(1) Lee, T.D.; Keana, J.F.W. J. Org. Chem. 1975, 40, 3145.

(2) CrystalStructure, version 3.7.0, Rigaku/MSC, The Woodlands, TX 77381, 2003.

(3) Gaussian03 revision C.02, Frisch, M.J.; Trucks, G.W.; Schlegel, H.B.; Scuseria, G.E.; Robb, M.A.; Cheeseman, J.R.; Montgomery, Jr., J.A.; Vreven, T.; Kudin, K.N.; Burant, J.C.; Millam, J.M.; Iyengar, S.S.; Tomasi, J.; Barone, V.; Mennucci, B.; Cossi, M.; Scalmani, G.; Rega, N.; Petersson, G.A.; Nakatsuji, H.; Hada, M.; Ehara, M.; Toyota, K.; Fukuda, R.; Hasegawa, J.; Ishida, M.; Nakajima, T.; Honda, Y.; Kitao, O.; Nakai, H.; Klene, M.; Li, X.; Knox, J.E.; Hratchian, H.P.; Cross, J.B.; Adamo, C.; Jaramillo, J.; Gomperts, R.; Stratmann, R.E.; Yazyev, O.; Austin, A.J.; Cammi, R.; Pomelli, C.; Ochterski, J.W.; Ayala, P.Y.; Morokuma, K.; Voth, G.A.; Salvador, P.; Dannenberg, J.J.; Zakrzewski, V.G.; Dapprich, S.; Daniels, A.D.; Strain, M.C.; Farkas, O.; Malick, D.K.; Rabuck, A.D.; Raghavachari, K.; Foresman, J.B.; Ortiz, J.V.; Cui, Q.; Baboul, A.G.; Clifford, S.; Cioslowski, J.; Stefanov, B.B.; Liu, G.; Liashenko, A.; Piskorz, P.; Komaromi, I.; Martin, R.L.; Fox, D.J.; Keith, T.; Al-Laham, M.A.; Peng, C.Y.; Nanayakkara, A.; Challacombe, M.; Gill, P.M.W.; Johnson, B.; Chen, W.; Wong, M.W.; Gonzalez, C.; Pople, J.A. Gaussian, Inc., Wallingford CT, 2004.

(4) Becke, A. D. J. Chem. Phys. 1993, 98, 5648.

(5) Lee, C.; Yang, W.; Parr, R. G. Phys. Rev. B 1998, 37, 785. 